\title{
Abnormalities in alternative splicing in diabetes: therapeutic targets
}

\author{
Zodwa Dlamini, Fortunate Mokoena and Rodney Hull \\ Research, Innovation \& Engagements Portfolio, Mangosuthu University of Technology, Durban, South Africa
}

Correspondence should be addressed to Z Dlamini

Email

Zodwa.Dlamini@mut.ac.za

\begin{abstract}
Diabetes mellitus (DM) is a non-communicable, metabolic disorder that affects 416 million individuals worldwide. Type 2 diabetes contributes to a vast $85-90 \%$ of the diabetes incidences while $10-15 \%$ of patients suffer from type 1 diabetes. These two predominant forms of DM cause a significant loss of functional pancreatic $\beta$-cell mass causing different degrees of insulin deficiency, most likely, due to increased $\beta$-cell apoptosis. Treatment options involve the use of insulin sensitisers, $\alpha$-glucosidase inhibitors, and $\beta$-cell secretagogues which are often expensive, limited in efficacy and carry detrimental adverse effects. Cost-effective options for treatment exists in the form of herbal drugs, however, scientific validations of these widely used medicinal plants are still underway. Alternative splicing (AS) is a co-ordinated post-transcriptional process in which a single gene generates multiple mRNA transcripts which results in increased amounts of functionally different protein isoforms and in some cases aberrant splicing leads to metabolic disease. In this review, we explore the association of AS with metabolic alterations in DM and the biological significance of the abnormal splicing of some pathogenic diabetes-related genes. An understanding of the molecular mechanism behind abnormally spliced transcripts will aid in the development of new diagnostic, prognostic and therapeutic tools.
\end{abstract}

\author{
Key Words \\ - alternative splicing \\ - pancreatic $\beta$-cells \\ - type 2 diabetes \\ - autoimmunity \\ - apoptosis
}

\section{Introduction}

Diabetes mellitus (DM) is a chronic disease characterised by hyperglycaemia as a result of the pancreas not making enough insulin or due to insulin resistance (World Health Organization 2016). According to the World Health Organization (World Health Organization 2016), DM is one of the major chronic diseases that affects 415 million adults as of 2015 , nearly all people who succumb to the condition are from low or middle income countries and $50-85 \%$ of the sufferers are unaware that they have diabetes. In 2012, an estimated 1.5 million deaths were directly caused by diabetes (World Health Organization 2016). There are two types of diabetes, namely: type 1 and 2 . In addition to these types gestational diabetes is the term given to the occurrence of hyperglycaemia during pregnancy. Other types of diabetes are associated with other diseases, such as pancreatitis and cystic fibrosis, or are drug induced due to thyroid hormones and glucocorticoid (Amod et al. 2012). Type 1 diabetes occurs when the pancreatic $\beta$-cell islets are destroyed, resulting in insulin deficiency; people with this type of diabetes require daily administration of insulin and are prone to ketoacidosis, coma and death (Eizirik et al. 2012, Semenya et al. 2012, World Health Organization 2016). Type 2 diabetes is the result of insulin resistance or due to the inability of the $\beta$-cells to produce enough insulin. Common symptoms of diabetes are frequent 
urination, excessive thirst, constant hunger, weight loss, vision changes as well as fatigue (Amod et al. 2012, World Health Organization 2016). Diabetic sufferers are also at risk of other diseases such as cardiac, peripheral arterial and cerebrovascular diseases (Alberti \& Zimmet 1998) that occur as a result of the impairment of angiogenesis. Angiogenesis is the growth of new blood vessels from pre-existing vessels which is crucial in wound healing, development of the placenta, muscle growth and the female reproductive cycle (Ladomery et al. 2007).

\section{Alternative splicing and diabetes}

\section{Alternative splicing}

It is now believed that up to $94 \%$ of human genes are alternatively spliced and that splicing is affected by an estimated $50 \%$ of disease causing mutations (Ward \& Cooper 2010). Splicing is the process where introns are removed from the pre-mRNA, followed by the joining of exons to form a mature mRNA. Alternative splicing (AS) is the selection of a subset of exons resulting in structurally and functionally different proteins generated from one gene (Feero et al. 2010). Figure 1 illustrates how different combinations of exons can be spliced together to form different mRNA isoforms from a single gene product. This provides cells with the ability to expand their catalogue of available proteins as well as the ability to rapidly alter their transcriptome. AS complexity is directly related to organismal complexity and is involved in the performance of all cellular functions (Lee \& Rio 2015). Disruption of AS has been shown to result in different types of diseases such as cancer and monogenic human diseases including diabetes (Pihlajamaki et al. 2011).

The splicing process is controlled and catalysed by a large ribonucleoprotein complex called the spliceosome. The spliceosome consists of five small nuclear ribonucleoprotein particles (snRNP), U1, U2, U4/U6 and U5, and 200 additional proteins (Lee \& Rio 2015). These core signals require the presence of additional cis-acting regulatory sequences to effectively regulate alternate splicing. Additionally there exist trans-acting splicing factors that function as promoters or repressors of splicing. A further layer of regulation is provided by the presence of binding site sequences that act as splicing enhancers or silencers. The proteins that bind to these sequences to regulate splicing are members of the SR (serine/argininerich proteins) and hnRNP (heterogeneous nuclear ribonucleoproteins) families (Eizirik et al. 2012). The protein isoforms generated through alternate splicing
A Cassette exons

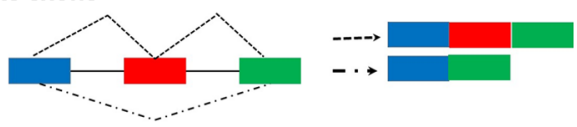

B Mutually exclusive exons

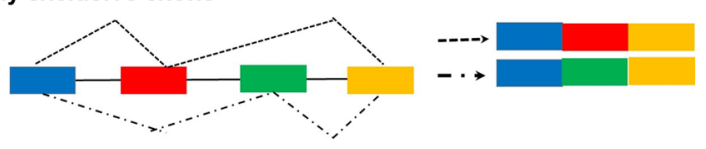

C Intron retention

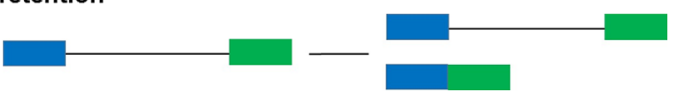

D Alternative 5' splice site

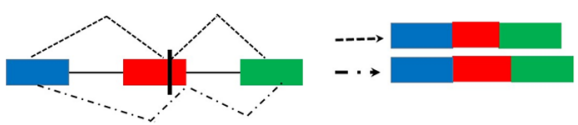

E Alternative 3' splice site

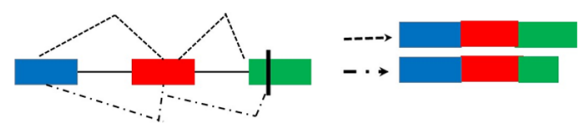

F Alternate promoters

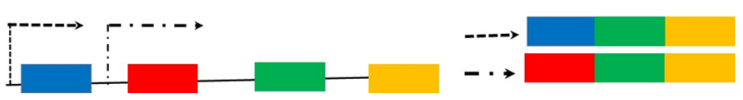

Figure 1

A depiction of different types of alternative splicing. The introns are marked with a black line and exons appear as red, blue, green and yellow rectangular objects. (A) Cassette exon is the result of exon exclusion. (B) Mutually exclusive exons occur when one exon is included while the other has been excised. (C) Intron retention occurs when an intron is retained and not excised. ( $D$ and $E$ ) Alternative splice sites involve the $5^{\prime}$ and $3^{\prime}$ exons being shortened due to internal splice sites. (F) Alternate promoters can change transcription initiation sites.

may have related, distinct or even opposite, antagonistic functions (Lee \& Rio 2015). Aberrant AS due to defects in cis-acting regulatory elements and trans-acting factors have been identified in autoimmune diseases such as multiple sclerosis (Evsyukova et al. 2010), myasthenia gravis (Gu et al. 2008) and systemic lupus erythematosus (Kozyrev et al. 2008).

\section{Diabetes, alternate splicing and apoptosis}

Type 1 diabetes is an autoimmune disease, where the immune system carries out an assault on the $\beta$-cells of the pancreas, resulting in pancreatic islet inflammation (insulitis) and $\beta$-cell apoptosis (Santin \& Eizirik 2013). The presentation of major histocompatibility complex (MHC) class II molecules on the surface of $\beta$ cells significantly increases the development of type 1 diabetes. Non-obese

Published by Bioscientifica Ltd 
diabetic (NOD) mice that lack active CD8+ cytotoxic T lymphocytes (CTL) do not develop diabetes and type 1 diabetics show an increased level of CTLs in the islets of the pancreas. NOD mice models have also demonstrated that CD4+ CTLs are also involved in $\beta$ cell killing (Tomita 2017). AS also occurs with a higher degree of frequency within the regions coding for the MHC region (Noble $\&$ Valdes 2011). It is known that the genetic risk of type 1 diabetes is highly associated with this MHC region (40\% of the genetic risk associated with type 1 diabetes) (Vandiedonck et al. 2011).

Type 2 diabetes is characterised by insulin resistance, defective insulin secretion, $\beta$-cell apoptosis and islet amyloid deposits (Table 1). Amyloid deposits consist of islet amyloid polypeptide (IAPP) which is secreted from $\beta$-cells into the blood in response to glucose-induced insulin secretion. Type 2 diabetics have decreased levels of soluble IAPP in the blood but increased levels of IAPP oligomers that kill $\beta$-cells by inducing membrane damage (Tomita 2016). There are genes whose function is linked to obesity and insulin resistance that are regulated by AS (Pihlajamaki et al. 2011) (Table 1). Examples of such aberrantly spliced genes in diabetes are ANO1, HNF-1a, IPF-1, GCK, SUR1, TCF7L2, VEGF and NOVA1 (Garin et al. 2008, Costantini et al. 2011, Schmid et al. 2012).

Two apoptotic pathways exist, the extrinsic (receptormediated) and intrinsic (mitochondria-driven) pathway. The extrinsic pathway is activated upon ligation of the cells surface death receptor(s), which in turn activates downstream effector mechanism orchestrated by the caspase family of cysteine proteases (Tomita 2016). Many genes that regulate apoptosis undergo AS to form protein isoforms with activity that is directly antagonistic to that of the original protein. Proteins in this group include CASPASE 2 (Wang et al. 1994), CASPASE 9 (Seol \& Billiar 1999), BCL-X (Montes et al. 2012), MCL-1 (Bingle et al. 2000 ) and the pro-apoptotic BH3 only protein BIM (Clybouw et al. 2012). These proteins are known to regulate cytokine-induced pancreatic $\beta$-cell apoptosis (Gurzov \& Eizirik 2011). The Bcl2 family of apoptosis regulators contain up to four Bcl2-homology (BH) domains. Splice variants that possess all four BH domains prevent mitochondrial outer membrane permeablization and, therefore, inhibit apoptosis. These include BCL2, BCL-XL and MCL1L. Splice variants that lack one or more of these domains are pro-apoptotic and include BID, $\mathrm{BAD}$ and $\mathrm{BAX}$. The spicing of these genes is controlled by a network of splicing factors that respond to apoptotic stimuli including SAM68, ASF/SF2, hnRNP F/H, SRP30C and RBM25 (Moore et al. 2010). The transcription factor
GLIS3 is required for pancreatic development and is associated with both type 1 and 2 diabetes. Decreased expression of GLIS3 leads to an increase in the levels of BIM dependant $\beta$-cell apoptosis. The increase in the level of apoptosis is due to a shift favouring the expression of the most pro-apoptotic splice isoform of the BH3-only protein BIM (Nogueira et al. 2013).

Multiple lines of evidence link both type 1 and type 2 diabetes to an increase in $\beta$ cell apoptosis. Caspase 3 inhibitors have been shown to prevent islet apoptosis. Multiple genes linked to apoptosis are de-regulated in multiple cell types leading to diabetes (Table 1). The expression of dominant negative death receptors such as FAS or the use of neutralizing antibodies to these receptors also delays the development of type 1 diabetes (Tomita 2016). Many signalling pathways also link diabetes to increases in apoptosis. In type 1 and 2 diabetes highglucose levels shift the balance of pro-apoptotic caspase family and anti-apoptotic Bcl proteins toward apoptosis, leading to $\beta$-cell death (Tomita 2016, 2017). In type 2 diabetes this may be controlled through the insulin receptor. The insulin receptor (INSR) has two isoforms, the shorter INSR-A, which is the result of skipping of exon 11 and INSR-B. The presence of insulin leads to activation of the RAS-MAPK/ERK signalling pathway, an increase in the level of the splicing factor SRSF1 and higher levels of INSR-B. Higher levels of INSR-A result from the absence of insulin, reduced MAPK-ERK signalling and sensitises $\beta$-cells to apoptosis (Malakar et al. 2016).

\section{The similarities between alternate splicing in neurons and $\beta$ cells}

AS plays an important role in the proper functioning of neurons and many neurological disorders are associated with aberrant AS. $\beta$ cells have a similar physiology and gene expression to neurons and insulin secretion is very similar to neurotransmitter secretion. Some neuron-enriched splicing regulators are also expressed in pancreatic $\beta$ cells and play a role in regulating $\beta$ cell survival and function. These include RNA-binding proteins (RBPs) that regulate the splicing of genes and are members of the ELAV1, NOVA and RBFOX families (Juan-Mateu et al. 2016, 2017).

NOVA1 is a splicing factor that is expressed at high levels in neurons, but it is also expressed at high levels in $\beta$ cells of the human and rat islets of Langerhans. It is considered to be a master regulator of AS, and in the brain, regulates splicing involved in the processes of migration, synaptic function and axon guidance. In $\beta$ cells NOVA 1 controls cell function and survival, regulating genes in

Published by Bioscientifica Ltd 
exocytosis, apoptosis, insulin receptor signalling, splicing and transcription (Villate et al. 2014, Juan-Mateu et al. 2017). Since NOVA 1 controls the splicing and expression of several transcription factors, it is able to regulate the transcription of a large number of genes. Genes whose transcription is controlled by NOVA1 include GABRG2, NEUROLIGIN and NEUREXIN family members, Inhibitory synapse-associated NEUROLIGIN and NEUREXIN binding partners and SNAP-25. Knockdown of NOVA1 led to the decreases in the expression levels of SNAP25 splice variant b. This splice variant triggers insulin secretion and, therefore, NOVA1 knockdown results in decreased insulin secretion (Juan-Mateu et al. 2017).

NOVA1 also regulates the splicing of the insulin receptor, favouring the expression of the INSR-A isoform following NOVA1 silencing. INSR-B expression leads to increased cell death via the extrinsic pathway of apoptosis, while the expression of INSR-A activates the intrinsic branch of apoptosis. The pro-inflammatory cytokines which induce $\beta$ cell death in type 1 diabetes, also inhibit NOVA1 expression in $\beta$ cells and NOVA1 knockdown also leads to an increase in BIM related apoptosis and a decrease in the transcription of serine/threonine protein kinase B (PKB)/AKT (Villate et al. 2014).

Three other neuron specific splicing regulators that are also expressed at high levels in $\beta$ cells are ELAV4 (HuD), RBFOX1 and RBFOX2. ELAV4 regulates splicing during the process of neurogenesis. In $\beta$ cells it plays a role in insulin translation. Knockdown of ELAV4 results in an increase in basal apoptosis levels, but a decrease in the levels of cytokine-induced apoptosis, suggesting that ELAV4 regulates different downstream transcripts. RBFOX1 and RBFOX2 are expressed in neurons, skeletal muscle and $\beta$ cells. The silencing of RBFOX1 and RBFOX2 increases insulin secretion by affecting actin depolymerization kinetics through the regulation of the alternate splicing of gelsolin. A decrease in the expression of the active isoform of gelsolin inhibits insulin secretion. The similar phenotype observed for RBFOX1 and RBFOX2 KD suggests that both RBPs regulate overlapping sets of transcripts in $\beta$ cells (Juan-Mateu et al. 2017).

\section{The use of Genome Wide Association Studies (GWAS) and RNA sequencing to study diabetes specific transcriptomes}

Several approaches with varying degrees of success have been used over the years to determine diabetes progression. Gene expression microarray analysis is one such approach that has been used, for example, to compare the expression profile of the genome of normal and diabetic retinas (Brucklacher et al. 2008, Freeman et al. 2009, Kandpal et al . 2012), and the results have highlighted that diabetes modulates the levels of transcripts that are involved in key pathways. Unfortunately microarrays are of limited use as depending on the array used, specific alternatively spliced isoforms as well as novel isoforms might be missed due to restrictions in the probe coverage. Massively parallel signature sequencing in the form of next-generation sequencing (NGS) and microarray analysis have been previously used to construct an inventory of insulinproducing $\beta$ cell gene expression. This database includes 7600 mRNA transcripts. Of these 2000 transcripts were upregulated, while 1400 were downregulated in $\beta$ cells compared to $\alpha$ cells and INS-1 cells (Kutlu et al. 2009).

Genome Wide Association Studies (GWAS) have been performed on individuals with type 1 diabetes and have resulted in the identification of more than 50 loci associated with the disease (Barrett et al. 2009, Storling $\&$ Pociot 2017). When these data were combined with protein-protein interaction and protein expression data, it was established that many of these genes code for proteins involved in the response of $\beta$ islet cells to cytokines and pro-inflammatory signals (Bergholdt et al. 2012, Storling \& Pociot 2017). RNA sequencing of whole transcriptomes has shown which splice variants of certain mRNAs are involved in the apoptosis of $\beta$ cells following exposure to the pro-inflammatory cytokines interleukin$1 \beta$ (IL-1 $\beta$ ) and interferon- $\gamma$ (IFN- $\gamma$ ). By combining this data with data from GWAS 29,776 transcripts were identified as expressed in human islets. Up to $35 \%$ of these undergo AS. Exposure of $\beta$ cells to cytokines caused substantial changes in spliced transcripts (Eizirik et al. 2012).

Type 2 diabetes is a polygenic disorder and only $5-10 \%$ of cases are due to a single gene. Multiple Genome Wide Analysis studies have been performed on type 2 diabetic individuals from multiple population groups. Up to 66 different susceptibility loci have been identified and at least 19 loci containing genes have been shown to increase the level of risk to type 2 diabetes. These include PPARG, KCNJ11, KCNQ1, CDKAL1, CDKN2A-2B, CDC123CAMK1D, MTNR1B, TCF7L2, TCF2(HNF1B), HHEX-KIF11IDE, JAZF1, IGF2BP2, SLC3OA8, THADA, ADAMTS9, WFS1, FTO, NOTCH2 and TSPAN8 (Zeggini et al. 2008, Yamauchi et al. 2010, Sun et al. 2016). An analysis of these studies from different population groups indicates that different genes are responsible for increased risks of type 2 diabetes in different population groups (Sun et al. 2016). http://jme.endocrinology-journals.org DOI: 10.1530/JME-17-0049
() 2017 Society for Endocrinology Printed in Great Britain
Published by Bioscientifica Ltd 
NGS has also been used to profile gene expression changes in a mouse model with diabetic retinopathy. Using RNA-seq, a study showed that alternatively spliced transcripts do arise throughout diabetic retinopathy progression and transcripts code for proteins that are involved in pathways such as inflammation, microvasculature formation, apoptosis, glucose metabolism, Wnt signalling, xenobiotic metabolism and photoreceptor biology (Kandpal et al. 2012). Application of RAGE and p38 MAP kinase inhibitors was shown to halt the expression of crystallin transcripts, which were upregulated in diabetic animals (Kandpal et al. 2012). When examining $\beta$-cell dysfunction in type 2 diabetes, a successful model has been developed using palmitatetreated human islet preparations to simulate the effect of high levels of saturated free fatty acids (FFAs). When NGS was used to examine the effect of palmitate on transcription patterns in $\beta$-cells, it was found that the transcription of 1325 genes was modified. These included genes involved with endoplasmic reticulum (ER) stress, transcription factors such as PAX4 and GATA, ubiquitin and proteasome function, autophagy and apoptosis. In terms of AS, palmitate modified the expression of 17 splicing factors and affected the splicing of 3525 alternatively spliced transcripts (Cnop et al. 2014). Alterations in the splicing of PAX4 have been detected in maturity-onset diabetes of the young (MODY). MODY type9 is associated with a PAX4 IVS7-1G > A mutation, which gives rise to aberrant mRNA splicing and PAX4 Q250 deletion. This leads to increased $\beta$ cell apoptosis when the cells are exposed to high levels of glucose (Sujjitjoon et al. 2016).

\section{Aberrantly spliced genes}

\section{Hepatocyte nuclear factor-1 alpha (HNF1-A)}

The hepatocyte nuclear factor 1 homeobox A (HNF1A) is a transcription factor implicated in MODY (Cappelli et al. 2009). MODY is the result of a mutation in a single gene and usually affects patients under the age of 25 no matter their ethnicity, weight or lifestyle (Cappelli et al. 2009). HNF1-A plays a role in regulating a number of genes such as insulin and maintains pancreatic function (Harries et al. 2006). The gene produces three isoforms due to AS and polyadenylation. These isoforms are: HNF1-A(A) which has 10 exons whilst HNF1-A(B) has 6 exons and finally HNF1$\mathrm{A}(\mathrm{C})$ has 7 exons (Fig. 2) (Harries et al. 2006). Mutations found on the isoforms are known to lower the amount of insulin produced by the pancreas thus leading to diabetes (Harries et al. 2006). A splicing mutation IVS4nt-1G $>T$ in intron 4 of the HNF1-A gene, which converts the AG

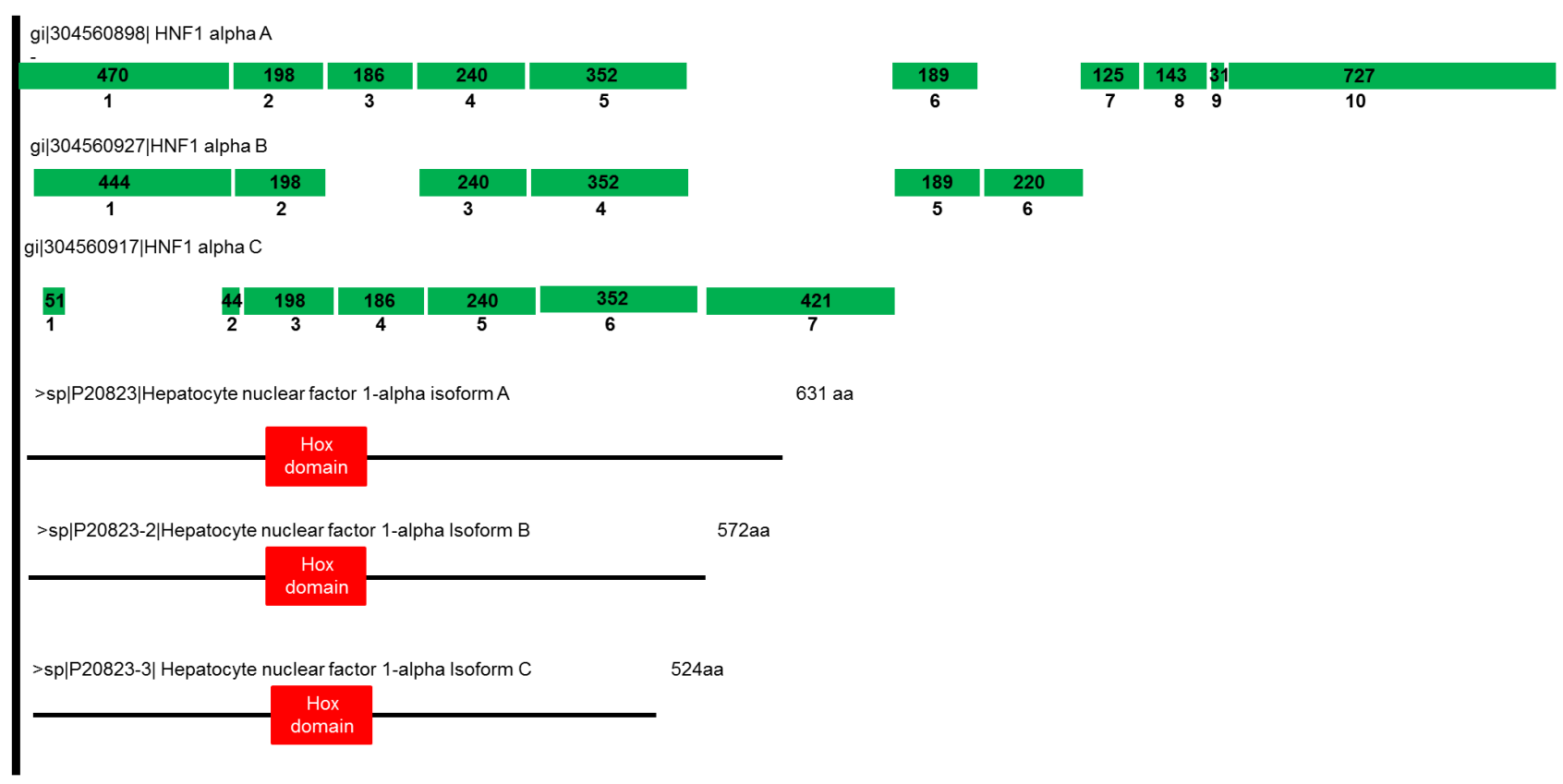

Figure 2

Alternate splicing of hepatocyte nuclear factor and the resulting protein isoforms. (A) Depicts the splice variants that play a role in the development of diabetes. The HNF1-A gene is alternatively spliced to give rise to three isoforms HNF1-A (10 exons), HNF1-A(B) (6 exons) and HNF1-A(C) (7 exons). (B) All the resulting protein isoforms still contain the HOX domain which is necessary for the protein to act as a transcription factor for initiating the expression of multiple genes in pancreatic islet cells and in the liver.

http://jme.endocrinology-journals.org DOI: 10.1530/JME-17-0049
๑ 2017 Society for Endocrinology Printed in Great Britain
Published by Bioscientifica Ltd 
to AT at a conserved splice acceptor site, was discovered and shown to cause skipping of exon 5 and might use the AG site for exon 6 or the cryptic site in intron 5 as splicing sites (Cappelli et al., 2009). The mutation causes an inclusion of intronic sequences resulting in a premature termination codon (PTC) that is degraded by nonsense-mediated decay (Cappelli et al. 2009). Another splicing mutation found in the HNF1-A gene is the G>A substitution that results in a glycine to serine conversion at codon 319 (G319S) (Harries et al. 2008). The base substitution occurs within the conserved intron 4 splice donor site and as a result two transcripts were detected due to an introduction of a PTC (Harries et al. 2008).

\section{Glucokinase (GCK)}

Glucokinase is the enzyme required to phosphorylate glucose to form glucose-6-phosphate (G6P). In this way it plays the role of detecting the levels of glucose and regulates insulin release. Glucokinase (GCK) and HNF1-A account for the majority of MODY cases in Europe (Lorini et al. 2009). A heterozygous synonymous substitution in the GCK exon4 (c.459T > G; p.Pro153Pro), identified in an Italian patient with MODY, has been shown to result in an aberrantly spliced in-frame transcript that lacks the last eight codons which under normal conditions are part of the glucose-binding pocket (Fig. 3) (Costantini et al. 2011). The substitution occurs $25 \mathrm{bp}$ upstream of the canonical donor splice site on intron 4 and the resulting abnormal splicing is believed to contribute to hyperglycaemia in patients (Costantini et al. 2011). In silico analysis done by Garin et al. (2008) predicted that the synonymous substitution of $G C K$ in exon 1 (c.45G>A; p.Glu17SerfsX161), located near an exon-intron boundary, causes the donor splice site not to be recognised leading to a PTC forming resulting in low levels of the protein (Garin et al. 2008, Lorini et al. 2009).

\section{ABCC8/SUR1}

ATP-binding cassette transporter sub-family $\mathrm{C}$ member 8 (ABCC8) is a member of the ATP-binding cassette family of transporters. It is involved in the transport of molecules across extra-and intracellular membranes. ABCC8 is a member of the MRP multi-drug resistance sub-family and is involved in ATP-sensitive potassium channel modulation. Pancreatic $\beta$-cells express the KATP channels that play an important role in insulin release and $A B C C 8$ encodes SUR1, a regulatory subunit of the KATP channels (Schmid et al. 2012). Different isoforms of the channels are found expressed in the heart, pancreatic islet cells, brain, blood vessels, etc. One such isoform, found in the pancreas of diabetic patients, is SUR1DM2 which lacks exon 2 as a result of a weak first splice acceptor site (Fig. 4) (Schmid et al. 2012). The truncated transcript is thought to decrease the sensitivity of the channels to ATP resulting in insulin inhibition. The presence of the SNP rs1048099 (Pro69Pro, T > C) on the gene of healthy individuals, generates an exonic splicing enhancer that results in the inclusion of exon 2 which confers resistance to diabetes (Sakamoto et al. 2007, Schmid et al. 2012).

\section{INS}

Mutations associated with permanent neonatal diabetes mellitus or infancy-onset diabetes found in the INS gene, which produces insulin, were reported to be associated

A

gi|221625432|glucokinase (hexokinase 4) regulator (GCKR) Isoform 1

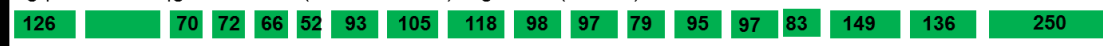

gi|221625432|glucokinase (hexokinase 4) regulator (GCKR) Isoform 2

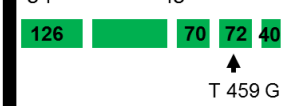

B

sp|Q14397| Glucokinase regulatory protein isoform $1 \quad 625$ amino acids

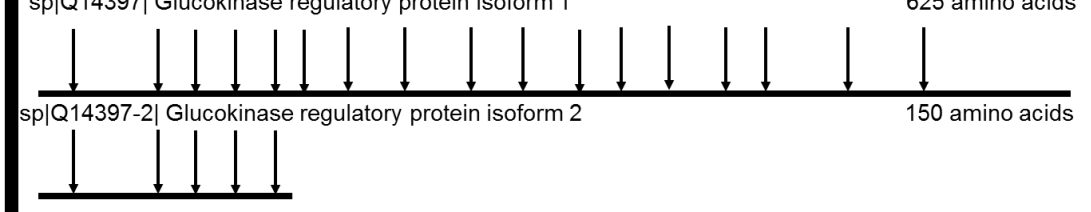

\begin{abstract}
Figure 3
Alternative splicing in the glucokinase regulatory gene and the resulting protein isoforms. (A) A heterozygous synonymous substitution in the GCK exon4 (c.459T > G; p.Pro153Pro) results in a truncated splice variant (B). This results in a truncated protein product. The arrows indicate the positions of the introns on the protein.
\end{abstract}

http://jme.endocrinology-journals.org DOI: 10.1530/JME-17-0049
(C) 2017 Society for Endocrinology Printed in Great Britain
Published by Bioscientifica Ltd 
A

gi|562815399|ATP-binding cassette, sub-family C (CFTR/MRP), member 8 (ABCC8), transcript variant 1

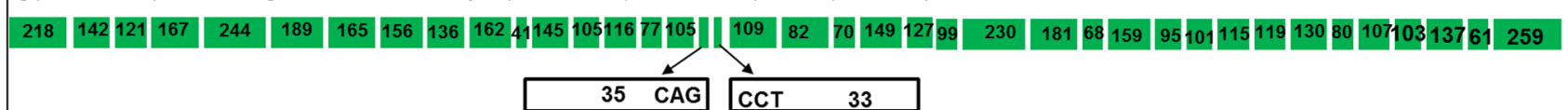

gi|562815399|ATP-binding cassette, sub-family C (CFTR/MRP), member 8 (ABCC8), transcript variant 2

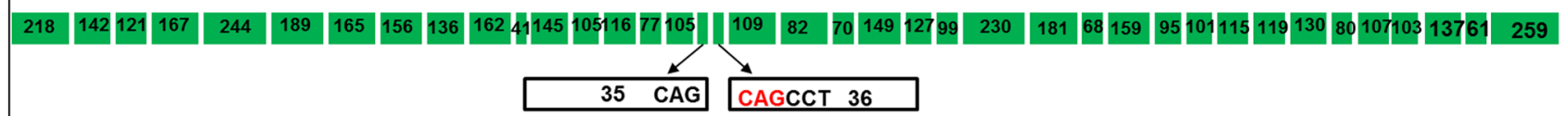

gi|562815399|ATP-binding cassette, sub-family C (CFTR/MRP), member 8 (ABCC8), transcript variant 3

218

B

sp|Q09428| ABCC8 Isoform $1 \quad 1581$ amino acids

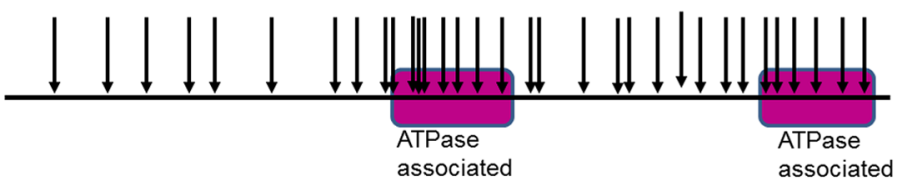

sp|Q09428-2|ABCC8 Isoform 2

1582 amino acids

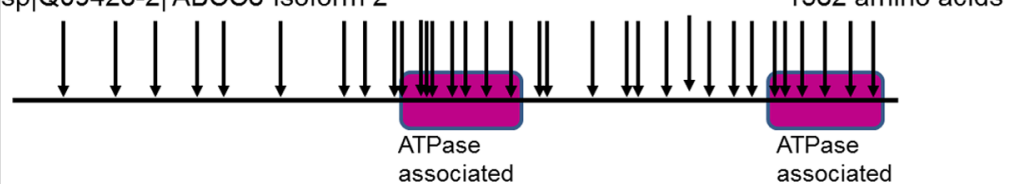

sp|Q09428-3|ABCC8 Isoform 3

50 amino acids

Figure 4

Alternative splicing in the ATP-binding cassette, sub-family $\mathrm{C}$ member 8 gene and the resulting protein isoforms: (A) The inclusion of an extra codon results in an increased in the size of exon 18. A small transcript contains only the first exon. (B) The two larger proteins still contain the two AAA domains which are involved in protein degradation, membrane fusion, DNA replication, microtubule dynamics, intracellular transport, transcriptional activation, protein refolding and the disassembly of protein complexes and aggregates. The arrows indicate the positions of the introns on the protein.

with mRNA splicing of the X-box binding protein-1 (XBP1) transcription factor (Colombo et al. 2008). The mutations identified in the INS gene leading to an increased expression of the shorter spliced form of the XBP1 gene are: LB6P (Leu to Pro substitution at residue 6 of the insulin B-B15B16 chain), LYdelinsH (replacement of Leu and Tyr by His at residues 15-16 of the B-chain), A6B11 CY (Cys to Tyr substitution at residue 6 of the insulin A-chain), LP (Leu to Pro substitution at residue 11 of the B-chain) and YA19X (Tyr to unknown amino acid at residue 19 of the A-A6A19 chain) (Fig. 5) (Colombo et al. 2008). The mutants CY and YX have only 2 of the 3 stabilising disulphide bonds of the INS gene resulting in insulin misfolding leading to ER stress and the expression of the spliced XBP1 variant (Colombo et al. 2008).

\section{VEGF}

The vascular endothelial growth factor (VEGF) gene plays an important role in angiogenesis. VEGF is the dominant angiogenic factor that is produced by podocytes in kidneys and functions with the help of its tyrosine kinase receptors VEGF-R1 and VEGF-R2 (MironidouTzouveleki et al. 2011, Liu et al. 2012). Many proteins that are alternatively spliced are known to be involved in angiogenesis and VEGF is amongst those. VEGF has many alternatively spliced isoforms that have been identified but of those relevant to this review are the VEGF165 and VEGF165b isoforms which are antagonistic in function (Ladomery et al. 2007). VEGF165 is pro-angiogenic whilst VEGF165b acts to inhibit VEGF165-mediated angiogenesis through its anti-angiogenic properties and also does not fully activate VEGF-R2 (Ladomery et al. 2007). VEGF codes for CDKPRR when the proximal $3^{\prime}$ splice site is selected to form VEGF165 or alternatively codes for SLTRKD when the distal 3' splice site is selected to form VEGF165b. VEGF165 is found in angiogenic tissues such as the placenta whilst VEGF165b is found in high concentrations in non-angiogenic tissues such as

Published by Bioscientifica Ltd 


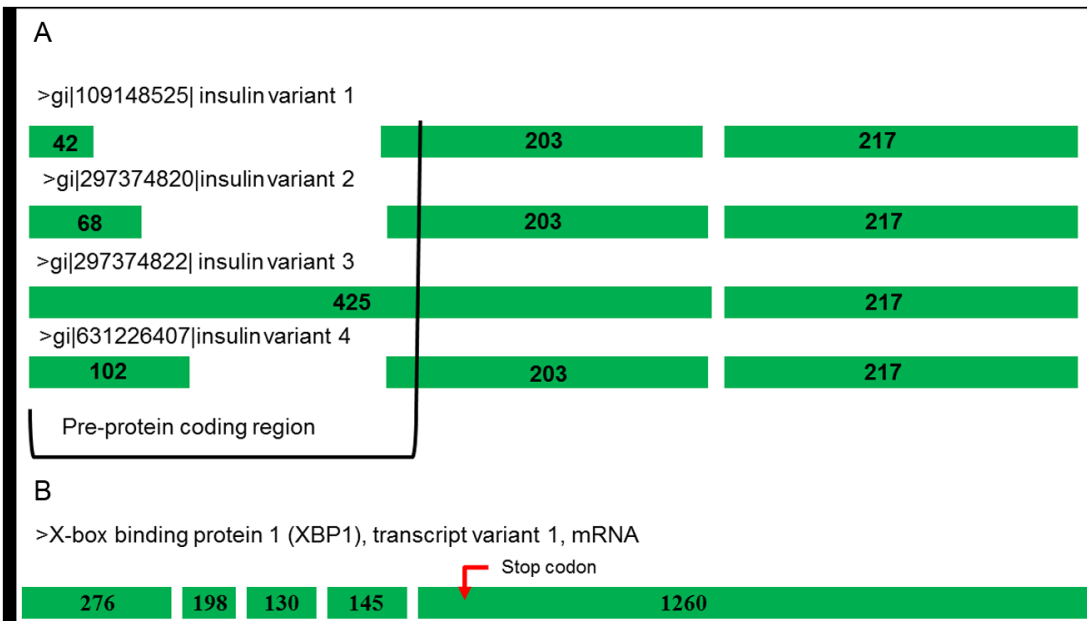

>X-box binding protein 1 (XBP1), transcript variant 2, mRNA

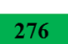

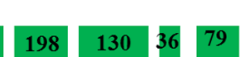

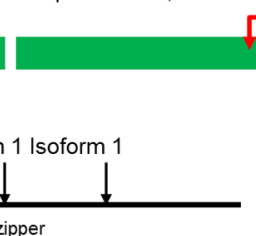

sp|P17861|X-box binding protein 1 Isoform 1

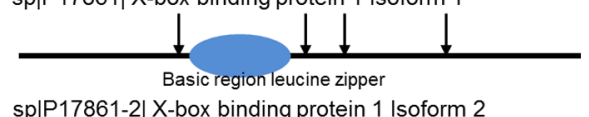

sp|P17861-2| X-box binding protein 1 Isoform 2

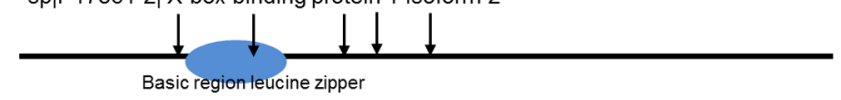

\section{Figure 5}

Alternative splicing in the Insulin and X-box binding protein and the resulting XBP protein isoforms. (A) The alternative splicing events in insulin variants occur in the pre-protein regions that are cleaved from the mature protein.

Mutations identified in the INS gene leading to an increased expression of the shorter spliced form of the XBP1 gene. (B) Alternative splicing in exon 4 leads to the generation of a new shorter exon arising from exon 4 . This alters the reading frame. (C) The resulting codon shift results in a longer protein isoform that shares no sequence similarity in the $\mathrm{C}$ terminus. The change in protein length is due to changes in the location of the stop codon. The arrows indicate the positions of the introns on the protein. the lung, skin and the vitreous (Ladomery et al. 2007). Impairment of angiogenesis, as is the case in diabetes, is known to cause improper wound healing, limb ischaemia leading to limb amputations and at times heart attacks (Mironidou-Tzouveleki et al. 2011). Recent investigations into the role of methylglyoxal (MGO) in angiogenesis impairment in diabetes show that MGO, a by-product of glycolysis and found in high concentrations in diabetic patients due to a deficient Glyoxalase 1 (GLO1), impaired angiogenesis by downregulating VEGF-R2 protein levels (Mironidou-Tzouveleki et al. 2011). The authors did not look at AS in this study, but the VEGF165b isoform could perhaps play a role in the reduction of VEGF-R2 levels and act as a marker or a switch which could be a therapeutic target for diabetes.

\section{CTLA-4}

Cytotoxic $\mathrm{T}$ lymphocyte-associated protein 4 (CTLA4) is also known as CD152 is a T cell surface receptor that functions to downregulate the immune system. This downregulation is the result of CTLA4 binding to CD80 or CD86. The presence of different isoforms of CTLA4 is associated with autoimmune disorders, including type 1 diabetes. Isoforms of this protein are generated by AS due to the presence of a single nucleotide polymorphism. This gives rise to the normal full length protein and a shorter soluble sCTLA4 that lacks the transmembrane domain encoded by exon 4 (Gerold et al. 2011, Mourich et al. 2014). Another isoform is the result of the absence of the ligand binding domain encoded by exon 2 and is called liCTLA-4. NOD mice have been used to study how these different isoforms can affect $\mathrm{T}$ cell response. NOD mice expressing the sCTL4 isoform are more prone to getting type 1 diabetes, while mice expressing liCTLA4 are more resistant to the getting the disease (Mourich et al. 2014). This is due to the activation of the T cells as those lacking receptors with a ligand binding site showed reduced activity while the soluble CTLA4 has an increased ability to activate $\mathrm{T}$ cells.

\section{DEAF-1}

Deformed epidermal autoregulatory factor 1 (DEAF1) is a zinc finger containing transcription factor that controls the expression of genes involved in antigen presentation in the tissue of the immune system or skin, including the pancreas. It is also involved in growth, development and epithelial cell division. The surface antigens whose expression is controlled by DEAF1 are needed for T cells to

Published by Bioscientifica Ltd 
Table 1 Some of the genes and cell types involved in apoptosis and the development of type 1 and type 2 diabetes.

\author{
Type 1 diabetes \\ CD8+ T cells cytotoxic T \\ lymphocytes \\ CD4+ T cells cytotoxic $T$ \\ lymphocytes
}

Lymphocytes (directing killing of $\beta$ cells)

T lymphocyte CTLA-4

Perforin and granzyme B

$\beta$ cells

Fas (CD95) TNF receptor (TNFR)

$B I D$

$B C l-x$ and $M C l-1$

$B C l-2$

Pancreatic lymph nodes

Deformed epidermal autoregulatory factor 1 (DEAF-1)

Type 2 diabetes

$\beta$ cells

Hepatocytes

Type 1 and type 2 diabetes Podocytes

Interleukin-1 (IL-1) IFNC and TNF

Islet amyloid polypeptide (IAPP)

$A B C C 8 / S U R 1$

Glucokinase

BH3-only genes Bid and Bad

Thioredox interacting protein (TXNIP) pro-apoptotic factor

NOX family of NADPH oxidases

HNF1-A

NOX family of NADPH oxidases
CTLA-4 splice variants influence $T$ cell function and immune response

Granule-mediated cytotoxicity is the dominant mechanism of killing $\beta$ cells by CTL. Granzyme B activates the pro-apoptotic molecule Bid

Cytokines activate NF-kB and STAT1 transcription factors, which induce nitric oxide synthase (iNOS) and production of toxic free radical NO

Fas is upregulated on beta cells after incubation with IL-1. Apoptosis of $\beta$ cells in NOD mice is prevented by Fas silencing

Deficiency of Bid protects islets from Fas-mediated apoptosis

Downregulation of these antiapoptotic genes by inflammatory cytokines leads to cell death

$\mathrm{BCl}-2$ overexpression prevents $\beta$ cell death

Dominant negative variant

(Deaf1-Var1) allow the persistence

of an increased number of auto-reactive T cells

TGF- $\beta$

VEGF
Deposits of amyloid leads to apoptosis due to endoplasmic reticulum (ER) stress

Truncated transcript is thought to decrease the sensitivity of KATP channels to ATP resulting in insulin inhibition

Isoforms without glucose-binding pocket contribute to hyperglycaemia in patients

Exposure of human islets to high levels of glucose resulted in upregulation

Glucose induces expression overexpression of TXNIP induces caspase 3-dependent beta cell apoptosis

Hyperglycaemia leads to an increase in ROS production

Different isoforms lower the amount of insulin produced by the pancreas leading to diabetes

Hyperglycaemia leads to an increase in ROS production

activating caspase 3 via p38MAPK and Smad7

Pro-and anti-angiogenic splice variants exist. In diabetes angiogenesis is impaired
Thomas et al. (2009)

Dudek et al. (2006)

Thomas et al. (2009)

Darville and Eizirik (1998)

Thomas et al. (2009)

McKenzie et al. (2008)

Allagnat et al. (2011)

McKenzie et al. (2008)

Yip et al. (2015)

Huang et al. (2007)

Sakamoto et al. (2007) Schmid et al. (2012)

Costantini et al. (2011)

Thomas et al. (2009)

Chen et al. (2008)

Guichard et al. (2008)

Harries et al. (2006)

Eid et al. (2013)

Li et al. (2004)

Mironidou-Tzouveleki et al. (2011) 
'learn' to recognise pathogens (Yip et al. 2015). DEAF1 is spliced into two different isoforms DEAF1 and a dominant negative isoform DEAF1-Var1. The expression level of DEAF-Var1 correlates with disease severity in NOD mice and the expression level of DEAF1-Var is reduced in NOD mice that do not develop diabetes (Yip et al. 2015).

\section{Therapies}

Diabetes is a common disease and many treatments for this serious disease have been developed over the years. Type 1 diabetes is treated by a daily administration of insulin, which is required to regulate blood sugar levels. The treatment of type 2 diabetes involves a combination of drug therapy (sometimes insulin is administered) as well as lifestyle changes that include physical activity, eating a healthy diet and refraining from tobacco usage. The suggested lifestyle changes help with maintaining a healthy body weight and reducing the risk of cardiovascular diseases such as heart attacks and strokes (World Health Organization 2016).

\section{Therapeutic targets}

Diabetic nephropathy (DN) is a diabetes-induced renal complication which is caused by VEGF impairment (Mironidou-Tzouveleki et al. 2011). VEGF plays an important role in the maintenance of kidney homeostasis and overexpression of the gene, and has been shown to lead to DN (Oltean et al. 2012). VEGF is crucial in angiogenesis and the absence of angiogenesis in the kidneys can be explained by the balanced presence of the isoforms VEGF165 and VEGF165b (MironidouTzouveleki et al. 2011, Oltean et al. 2012) recently showed that overexpression of the isoform VEGF165b decreases damage to the kidneys by delaying DN (Oltean et al. 2012) and the same authors postulate that the inhibition of the serine-arginine protein kinase 1 (SRPK1), a known splicing factor, can enhance the splicing of the VEGF165b isoforms.

\section{Traditional herbal treatments}

The anti-diabetic properties of several herbal agents have been extensively reviewed. For an informative review on the botanical names, country of origin, part used and bioactive agents of more than 400 hypoglycaemic plant species please see Malviya et al. (2010). The common practice is to use herbal formulations that have been recommended as modern medicines based on animal studies and clinical evidence. Clinical studies looking at the following medicinal plants: Aegle marmelos, Allium cepa, Gymnema sylvestre, Momordica charantia, Ocimum sanctum, Nigella sativa, Ocimum sanctum, Panax quinquefolius, Salacia reticulata, Silybum marianum and Trigonella foenum-graecum have demonstrated their hypoglycaemic and, in some cases, hypolipidemic activities in diabetic individuals (Chiniwala \& Jabbour 2011). Also, G. sylvestre, M. charantia, S. marianum and T. foenum-graecum are the most widely used for the treatment of diabetes. $M$. charantia (Linn/Family: Cucurbaceae) whose fruit is known as karela/corilla, or bitter gourd has widespread usage in India, East Africa, Central and South America (Joseph \& Jini 2013). The fresh juice of bitter gourd has been shown to treat the clinical symptoms of diabetes. Animal studies have reported significant reductions in the blood sugar after the administration of $M$. charantia (freshly prepared juice or dried fruit) normal and alloxan diabetic rabbits (Atta Ur \& Zaman 1989, Jaiswal et al. 2009, Afolayan \& Sunmonu 2010).

Unfortunately the cost of drugs used to treat diabetes is out of reach for most people especially the low income earners as well as those living in rural areas (Semenya et al. 2012). In South Africa, most of the low income earners comprise the majority of the population, with the largest number coming from the black population. Due to tradition as well as the affordability factor, many black patients rely on traditional healers that use indigenous plants to treat diseases (Semenya et al. 2012). South African medicinal plants with anti-diabetic properties are Mimusops zeyheri, Helichrysum caespititium, Aloe marlothii, Hypoxis iridifolia, Moringa oleifera, Plumeria obtusa, Momordica balsamina, Artemisia afra, Brachylaena discolour and Cannabis sativa (Afolayan \& Sunmonu 2010, Semenya et al. 2012). The part of the plants usually used for diabetes treatment are the leaves and the roots but there are certain plants like Helichrysum petiolare and Momordica foetida, where the whole plant is used for treatment (Afolayan \& Sunmonu 2010).

Different preparation methodologies are used by traditional healers for the different anti-diabetic medicinal plants. These preparations include squeezing and drinking the juice from the leaves, cooking the whole plant or parts thereof, pounding and drinking with warm water or with soft porridge (Semenya et al. 2012), whilst in vitro and/or in vivo preparations in the lab involve ethanol/ aqueous/chloroform extractions (Atta Ur \& Zaman 1989, Jaiswal et al. 2009, 2013, Kibiti \& Afolayan 2015).

Published by Bioscientifica Ltd. 
In literature only one study has so far reported the effect the anti-diabetic plant extracts have on the alternatively spliced products in diabetes. Mao et al. (2007) examined the use of Astragalus polysaccharide (APS), a plant extract of Astragalus membranaceus Bunge (Leguminosae), a long staple of traditional Chinese medicine used to treat diabetes (Mao et al. 2007). The in vivo as well as the in vitro effects of APS were investigated using KKAy mice (a model for severely obese and insulin resistant mice) as well as HepG2 cells (liver cells with high-glucose content), respectively. Certain stimuli such as hyperglycaemia are known to cause ER stress resulting in protein unfolding leading to obesity, insulin resistance and type 2 diabetes (Ozcan et al. 2004). Transcription and splicing of the $X B P-1$ gene is used as a marker for ER stress and it was found that the expression as well as the splicing of XBP-1 in both the APS treated KKAy mice and the APS treated HepG2 cells was greatly reduced when compared to the untreated controls. It was concluded that APS halts ER stress in diabetes by its hypoglycaemic and insulinsensitising actions (Mao et al. 2007, Colombo et al. 2008, van Huyssteen et al. 2011).

\section{Exercise}

As mentioned earlier, exercising is recommended as a form of regulating diabetes as it ensures that one's weight is maintained at a healthier level. Kaminska et al. (2012), recently showed that surgery induced weight loss does have an effect on alternatively spliced products in diabetes. The authors specifically examined the gene TCF7L2 which consists of 18 exons and is prone to AS, and whose variants are known to contribute to diabetes (Pihlajamaki et al. 2011, Kaminska et al. 2016). As a result of weight loss, the authors showed that the short mRNA variant, i.e. the variant lacking exons 12, 13 and 13a, was reduced in both subcutaneous fat and in the liver. The short variant is associated with hyperglycaemia and dysfunctional insulin action in the adipose tissues of type 2 diabetes patients.

\section{RNAi and antisense oligonucleotides}

The use of RNAi as a potential therapy for the treatment of many diseases relies on the ability of these small, doublestranded RNA molecules to catalyse the degradation of specific mRNAs that are complementary to their antisense strand. RNAi has been used to target numerous molecules involved in type 1 and type 2 diabetes. For reviews regarding the use of RNAi in the treatment of diabetes see Kokil et al. (2015) and Czech et al. (2011). RNAi has been used to control the expression of pro-and anti-apoptotic BCL isoforms, BCL-xS and BCL-xL, by decreasing the expression of both SAM68 and hnRNPA1 to increase the levels of BCL-xL and by decreasing the expression of SF3B1/SAP155 to increase the levels of BCL-xS (Moore et al. 2010).

Antisense oligonucleotides are short single-stranded segments of DNA and can function to affect the expression of alternatively spliced protein isoforms by either blocking the expression of that particular protein or by initiating exon skipping. To achieve this these oligonucleotides target specific exons in the pre-mRNA, leading to them being skipped or included, by masking silencing sites, during splicing (Spitali \& Aartsma-Rus 2012). Studies indicate that diabetic retinopathy could be treated through the use of antisense oligonucleotides to regulate the expression of isoforms of different growth factors. Neovascularization due to an upregulation in angiogenesis is a hallmark of proliferative diabetic retinopathy. Loss of vision results from the haemorrhage or retinal detachment as new blood vessels become surrounded by fibrous tissue which contracts and breaks the new vessels. Angiogenesis is kept in balance in healthy tissue due to a balance between inducers (VEGF and other factors) and inhibitors (e.g., pigment epithelium-derived factor) of angiogenesis. Hypoxia-inducible factor- 1 activates the transcription of several pro-angiogenic growth factors, including VEGF, EPO, placental growth factor, angiopoietin-2 (Ang-2), and platelet-derived growth factor (Hnik et al. 2009). Antisense oligonucleotides may be used to downregulate the expression of specific pro-angiogenic isoforms of VEGF and these other growth factors by targeting RNA sequences unique to these isoforms. Antisense oligonucleotides can also be used to switch from the regular CTLA-4 to the form lacking the B7 ligand binding domain (liCTLA-4) by using an antisense oligonucleotide to target the splice acceptor site for exon 2 . Mice treated with these antisense oligonucleotides showed a reduction in the incidence of insulitis and diabetes (Mourich et al. 2014).

\section{Oral hypoglycaemic therapy (insulin secretagogues, insulin sensitisers)}

Different oral hypoglycaemic agents have been developed to help with the maintenance of blood glucose levels of diabetics by correcting for insulin resistance and inadequate insulin secretion. These oral hypoglycaemic http://jme.endocrinology-journals.org DOI: 10.1530/JME-17-0049
() 2017 Society for Endocrinology Printed in Great Britain
Published by Bioscientifica Ltd 
agents include: insulin secretagogues (sulphonylureas, meglitinides), insulin sensitisers (biguanides, metformin and thiazolidinediones) and $\alpha$-glucosidase inhibitors (miglitol, acarbose) (Bolli 1997, Olokoba et al. 2012).

The insulin secretagogues, sulphonylureas, improve the diabetic state of patients by binding to the sulphonylureas receptors on functional $\beta$-cells of the pancreas. Therefore, inhibiting ATP354 sensitive $\mathrm{K}^{+}$ channels leads to depolarization, an influx of $\mathrm{Ca}^{2+}$ and insulin secretion (Kawaki et al. 1999). The mode of action for the rapid or short-acting secretagogues; meglitinides, is similar to that of the sulphonylureas. Thus, meglitinides have been developed to have a rapid onset and a short metabolic half-life, resulting in preferential targeting of post-prandial hyperglycaemia and decreased risk for hypoglycaemia later on (Nattrass \& Lauritzen 2000).

Biguanides (metformin) has traditionally been used to treat diabetes in Europe. Its associated clinical benefits are weight loss, increased sensitivity to insulin, suppression of hepatic glucose production, enhanced glucose uptake by phosphorylating glucose transporter (GLUT)-enhancer factor, accelerated fatty acid oxidation, and decreased the absorption of glucose from the gastrointestinal tract (Collier et al. 2006). It is also thought that insulin sensitivity is improved and mediated via modification of post-receptor signalling in the insulin pathway. Metformin is known to activate adenosine $5^{\prime}$-monophosphate (AMP)-activated protein kinase which plays a role in the expression of hepatic gluconeogenic genes (DeFronzo 1999). It also acts by lowering the rate of gluconeogenesis in the presence of insulin. It is though that it performs this action by altering the relative expression of the different isoforms of the insulin receptor (Kacalska et al. 2005).

Thiazolidinediones (pioglitazone and rosiglitazone), were the first drugs to address the problem of insulin resistance in type 2 diabetes patients. The role of thiazolidinediones or TZDs as insulin sensitisers is to increase the transcription of PPARs (peroxisome proliferator-activated receptors) and increase the uptake of glucose by binding to PPARS a group of receptor molecules inside the cell nucleus, specifically $\operatorname{PPAR}$ (gamma) (Kahn et al. 2000). FFAs and eicosanoids serve as ligands for PPAR receptors. When activated the ligands migrate to the DNA and activate the transcriptions of specific genes. TZDs reverse insulin resistance by acting on muscle, fat and to a lesser extent liver to increase glucose utilization and diminish glucose production. Furthermore, TZDs, like metformin, require the presence of insulin to mediate a blood glucose-lowering effect (Kahn et al. 2000).

\section{Conclusion}

Splice variants of genes involved in the apoptotic pathway as well as those involved in insulin resistance and obesity have been reviewed and demonstrate the importance that the alternatively spliced isoforms of these genes may play in diabetes. Novel technologies such as microarray and high throughput data techniques such as NGS are cutting edge tools used to understand diabetic mellitus-specific abnormal splice variants and possibly lead to aetiology of the disease. Exploring the research mechanism of AS and the combinations of cis-trans elements that discriminate splice sites and regulate splicing patterns, might aid in the identification of diagnostic markers and predict sensitivity to certain drugs (Gabut et al. 2011, de Almeida \& CarmoFonseca 2012). Also, experimental approaches to apoptosis and insulin resistance are essential to the progress of research in the field of DM. Indeed, chemical compounds and medicinally bioactive compounds may be used to target splice variants of apoptosis-associated and insulin resistant genes. Treatment options to correct for abnormal splicing of these genes is yet to produce therapeutic benefits nevertheless, RNA interference, antisense oligonucleotides, splice-switching oligonucleotides and monoclonal antibodies remain promising new strategies to target abnormal splicing.

\section{Declaration of interest}

The authors declare that there is no conflict of interest that could be perceived as prejudicing the impartiality of this review.

\section{Funding}

This work was funded by the National Research Foundation (NRF) of South Africa and the South African Medical Research Council (SA-MRC).

\section{References}

Afolayan JA \& Sunmonu OT 2010 In vivo studies on antidiabetic plants used in South African herbal medicine. Journal of Clinical Biochemistry and Nutrition 47 98-106. (doi:10.3164/jcbn.09-126R)

Alberti KG \& Zimmet PZ 1998 Definition, diagnosis and classification of diabetes mellitus and its complications. Part 1: diagnosis and classification of diabetes mellitus provisional report of a $\mathrm{WHO}$ consultation. Diabetic Medicine 15 539-553. (doi:10.1002/(SICI)10969136(199807)15:7<539::AID-DIA668>3.0.CO;2-S)

Allagnat F, Cunha D, Moore F, Vanderwinden JM, Eizirik DL \& Cardozo AK 2011 Mcl-1 downregulation by pro-inflammatory cytokines and palmitate is an early event contributing to beta-cell apoptosis. Cell Death and Differentiation 18 328-337. (doi:10.1038/cdd.2010.105)

Amod A, Ascott-Evans BH, Berg GI, Blom DJ, Brown SL, Carrihill MM, Dave JA, Distiller LA, Ganie YN, Grobler N, et al. 2012 The 2012 SEMDSA Guideline for the management of type 2 diabetes. Journal of http://jme.endocrinology-journals.org DOI: 10.1530/JME-17-0049
๑) 2017 Society for Endocrinology Printed in Great Britain
Published by Bioscientifica Ltd 
Endocrinology, Metabolism and Diabetes of South Africa 17 S1-S95. (doi: 10.1080/22201009.2012.10872287)

Atta Ur R \& Zaman K 1989 Medicinal plants with hypoglycemic activity. Journal of Ethnopharmacology 26 1-55. (doi:10.1016/03788741(89)90112-8)

Barrett JC, Clayton DG, Concannon P, Akolkar B, Cooper JD, Erlich HA, Julier C, Morahan G, Nerup J, Nierras C, et al. 2009 Genomewide association study and meta-analysis find that over 40 loci affect risk of type 1 diabetes. Nature Genetics 41 703-707. (doi:10.1038/ng.381)

Bergholdt R, Brorsson C, Palleja A, Berchtold LA, Floyel T, BangBerthelsen CH, Frederiksen KS, Jensen LJ, Storling J \& Pociot F 2012 Identification of novel type 1 diabetes candidate genes by integrating genome-wide association data, protein-protein interactions, and human pancreatic islet gene expression. Diabetes 61 954-962. (doi:10.2337/db11-1263)

Bingle CD, Craig RW, Swales BM, Singleton V, Zhou P \& Whyte MK 2000 Exon skipping in Mcl-1 results in a bcl-2 homology domain 3 only gene product that promotes cell death. Journal of Biological Chemistry 275 22136-22146. (doi:10.1074/jbc.M909572199)

Bolli GB 1997 Hypoglycaemia unawareness. Diabetes and Metabolism 23 (Supplement 3) 29-35.

Brucklacher RM, Patel KM, VanGuilder HD, Bixler GV, Barber AJ, Antonetti DA, Lin CM, LaNoue KF, Gardner TW, Bronson SK, et al. 2008 Whole genome assessment of the retinal response to diabetes reveals a progressive neurovascular inflammatory response. $B M C$ Medical Genomics 1 26. (doi:10.1186/1755-8794-1-26)

Cappelli A, Tumini S, Consoli A, Carinci S, Piersanti C, Ruggiero G, Simonella G, Soletti F, Staffolani P \& Pianese L 2009 Novel mutations in GCK and HNF1A genes in Italian families with MODY phenotype. Diabetes Research and Clinical Practice 83 e72-e74. (doi:10.1016/j.diabres.2008.12.007)

Chen J, Saxena G, Mungrue IN, Lusis AJ \& Shalev A 2008 Thioredoxininteracting protein: a critical link between glucose toxicity and betacell apoptosis. Diabetes 57 938-944. (doi:10.2337/db07-0715)

Chiniwala N \& Jabbour S 2011 Management of diabetes mellitus in the elderly. Current Opinion in Endocrinology, Diabetes and Obesity 18 148-152. (doi:10.1097/MED.0b013e3283444ba0)

Clybouw C, Merino D, Nebl T, Masson F, Robati M, O'Reilly L, Hubner A, Davis RJ, Strasser A \& Bouillet P 2012 Alternative splicing of Bim and Erk-mediated Bim(EL) phosphorylation are dispensable for hematopoietic homeostasis in vivo. Cell Death and Differentiation 19 1060-1068. (doi:10.1038/cdd.2011.198)

Cnop M, Abdulkarim B, Bottu G, Cunha DA, Igoillo-Esteve M, Masini M, Turatsinze JV, Griebel T, Villate O, Santin I, et al. 2014 RNA sequencing identifies dysregulation of the human pancreatic islet transcriptome by the saturated fatty acid palmitate. Diabetes $\mathbf{6 3}$ 1978-1993. (doi:10.2337/db13-1383)

Collier CA, Bruce CR, Smith AC, Lopaschuk G \& Dyck DJ 2006 Metformin counters the insulin-induced suppression of fatty acid oxidation and stimulation of triacylglycerol storage in rodent skeletal muscle. American Journal of Physiology: Endocrinology and Metabolism 291 E182-E189. (doi:10.1152/ajpendo.00272.2005)

Colombo C, Porzio O, Liu M, Massa O, Vasta M, Salardi S, Beccaria L, Monciotti C, Toni S, Pedersen O, et al. 2008 Seven mutations in the human insulin gene linked to permanent neonatal/infancy-onset diabetes mellitus. Journal of Clinical Investigation 118 2148-2156. (doi:10.1172/JCI33777).

Costantini S, Prandini P, Corradi M, Pasquali A, Contreas G, Pignatti PF, Pinelli L, Trabetti E \& Maffeis C 2011 A novel synonymous substitution in the GCK gene causes aberrant splicing in an Italian patient with GCK-MODY phenotype. Diabetes Research and Clinical Practice 92 e23-e26. (doi:10.1016/j.diabres.2011.01.014)

Czech MP, Aouadi M \& Tesz GJ 2011 RNAi-based therapeutic strategies for metabolic disease. Nature Reviews Endocrinology 7 473-484. (doi:10.1038/nrendo.2011.57)
Darville MI \& Eizirik DL 1998 Regulation by cytokines of the inducible nitric oxide synthase promoter in insulin-producing cells. Diabetologia 41 1101-1108. (doi:10.1007/s001250051036)

de Almeida SF \& Carmo-Fonseca M 2012 Design principles of interconnections between chromatin and pre-mRNA splicing. Trends in Biochemical Sciences 37 248-253. (doi:10.1016/j.tibs.2012.02.002)

DeFronzo RA 1999 Pharmacologic therapy for type 2 diabetes mellitus. Annals of Internal Medicine 131 281-303. (doi:10.7326/0003-4819131-4-199908170-00008)

Dudek NL, Thomas HE, Mariana L, Sutherland RM, Allison J, Estella E, Angstetra E, Trapani JA, Santamaria P, Lew AM, et al. 2006 Cytotoxic T-cells from T-cell receptor transgenic NOD8.3 mice destroy betacells via the perforin and Fas pathways. Diabetes 55 2412-2418. (doi:10.2337/db06-0109)

Eid AA, Ford BM, Bhandary B, de Cassia Cavaglieri R, Block K, Barnes JL, Gorin Y, Choudhury GG \& Abboud HE 2013 Mammalian target of rapamycin regulates Nox4-mediated podocyte depletion in diabetic renal injury. Diabetes 62 2935-2947. (doi:10.2337/db12-1504)

Eizirik DL, Sammeth M, Bouckenooghe T, Bottu G, Sisino G, IgoilloEsteve M, Ortis F, Santin I, Colli ML, Barthson J, et al. 2012 The human pancreatic islet transcriptome: expression of candidate genes for type 1 diabetes and the impact of pro-inflammatory cytokines. PLoS Genetics 8 e1002552. (doi:10.1371/journal.pgen.1002552)

Evsyukova I, Somarelli JA, Gregory SG \& Garcia-Blanco MA 2010 Alternative splicing in multiple sclerosis and other autoimmune diseases. RNA Biology 7 462-473. (doi:10.4161/rna.7.4.12301)

Feero WG, Guttmacher AE \& Collins FS 2010 Genomic medicine - an updated primer. New England Journal of Medicine 362 2001-2011. (doi:10.1056/NEJMra0907175)

Freeman WM, Bixler GV, Brucklacher RM, Walsh E, Kimball SR, Jefferson LS \& Bronson SK 2009 Transcriptomic comparison of the retina in two mouse models of diabetes. Journal of Ocular Biology, Diseases, and Informatics 2 202-213. (doi:10.1007/s12177-009-9045-3)

Gabut M, Samavarchi-Tehrani P, Wang X, Slobodeniuc V, O'Hanlon D, Sung HK, Alvarez M, Talukder S, Pan Q, Mazzoni EO, et al. 2011 An alternative splicing switch regulates embryonic stem cell pluripotency and reprogramming. Cell 147 132-146. (doi:10.1016/j. cell.2011.08.023)

Garin I, Rica I, Estalella I, Oyarzabal M, Rodriguez-Rigual M, San Pedro JI, Perez-Nanclares G, Fernandez-Rebollo E, Busturia MA, Castano L, et al. 2008 Haploinsufficiency at GCK gene is not a frequent event in MODY2 patients. Clinical Endocrinology 68 873-878. (doi:10.1111/ j.1365-2265.2008.03214.x)

Gerold KD, Zheng P, Rainbow DB, Zernecke A, Wicker LS \& Kissler S 2011 The soluble CTLA-4 splice variant protects from type 1 diabetes and potentiates regulatory T-cell function. Diabetes 60 1955-1963. (doi:10.2337/db11-0130)

Gu M, Kakoulidou M, Giscombe R, Pirskanen R, Lefvert AK, Klareskog L \& Wang X 2008 Identification of CTLA-4 isoforms produced by alternative splicing and their association with myasthenia gravis. Clinical Immunology 128 374-381. (doi:10.1016/j.clim.2008.05.006)

Guichard C, Moreau R, Pessayre D, Epperson TK \& Krause KH 2008 NOX family NADPH oxidases in liver and in pancreatic islets: a role in the metabolic syndrome and diabetes? Biochemical Society Transactions 36 920-929. (doi:10.1042/BST0360920)

Gurzov EN \& Eizirik DL 2011 Bcl-2 proteins in diabetes: mitochondrial pathways of beta-cell death and dysfunction. Trends in Cell Biology 21 424-431. (doi:10.1016/j.tcb.2011.03.001)

Harries LW, Ellard S, Stride A, Morgan NG \& Hattersley AT 2006 Isomers of the TCF1 gene encoding hepatocyte nuclear factor-1 alpha show differential expression in the pancreas and define the relationship between mutation position and clinical phenotype in monogenic diabetes. Human Molecular Genetics 15 2216-2224. (doi:10.1093/ $\mathrm{hmg} / \mathrm{dd} 1147)$

Harries LW, Sloman MJ, Sellers EA, Hattersley AT \& Ellard S 2008 Diabetes susceptibility in the Canadian Oji-Cree population is

Published by Bioscientifica Ltd. 
moderated by abnormal mRNA processing of HNF1A G319S transcripts. Diabetes 57 1978-1982. (doi:10.2337/db07-1633)

Hnik P, Boyer DS, Grillone LR, Clement JG, Henry SP \& Green EA 2009 Antisense oligonucleotide therapy in diabetic retinopathy. Journal of Diabetes Science and Technology 3 924-930. (doi:10.1177/1932296809 00300440)

Huang CJ, Lin CY, Haataja L, Gurlo T, Butler AE, Rizza RA \& Butler PC 2007 High expression rates of human islet amyloid polypeptide induce endoplasmic reticulum stress mediated beta-cell apoptosis, a characteristic of humans with type 2 but not type 1 diabetes. Diabetes 56 2016-2027. (doi:10.2337/db07-0197)

Jaiswal D, Kumar Rai P, Kumar A, Mehta S \& Watal G 2009 Effect of Moringa oleifera Lam. leaves aqueous extract therapy on hyperglycemic rats. Journal of Ethnopharmacology 123 392-396. (doi:10.1016/j.jep.2009.03.036)

Jaiswal D, Rai PK, Mehta S, Chatterji S, Shukla S, Rai DK, Sharma G, Sharma B, Khair S \& Watal G 2013 Role of Moringa oleifera in regulation of diabetes-induced oxidative stress. Asian Pacific Journal of Tropical Medicine 6 426-432. (doi:10.1016/S1995-7645(13)60068-1)

Joseph B \& Jini D 2013 Antidiabetic effects of Momordica charantia (bitter melon) and its medicinal potency. Asian Pacific Journal of Tropical Disease 3 93-102. (doi:10.1016/S2222-1808(13)60052-3)

Juan-Mateu J, Villate O \& Eizirik DL 2016 Mechanisms in endocrinology: alternative splicing: the new frontier in diabetes research. European Journal of Endocrinology 174 R225-R238. (doi:10.1530/EJE-15-0916)

Juan-Mateu J, Rech TH, Villate O, Lizarraga-Mollinedo E, Wendt A, Turatsinze JV, Brondani LA, Nardelli TR, Nogueira TC, Esguerra JL, et al. 2017 Neuron-enriched RNA-binding proteins regulate pancreatic beta cell function and survival. Journal of Biological Chemistry 292 3466-3480. (doi:10.1074/jbc.M116.748335)

Kacalska O, Krzyczkowska-Sendrakowska M, Milewicz T, ZabinskaPopiela M, Bereza T, Krzysiek-Maczka G \& Krzysiek J 2005 Molecular action of insulin-sensitizing agents. Endokrynologia Polska $\mathbf{5 6}$ 308-313.

Kahn CR, Chen L \& Cohen SE 2000 Unraveling the mechanism of action of thiazolidinediones. Journal of Clinical Investigation 106 1305-1307. (doi:10.1172/JCI11705)

Kaminska D, Kuulasmaa T, Venesmaa S, Kakela P, Vaittinen M, Pulkkinen L, Paakkonen M, Gylling H, Laakso M \& Pihlajamaki J 2012 Adipose tissue TCF7L2 splicing is regulated by weight loss and associates with glucose and fatty acid metabolism. Diabetes $\mathbf{6 1}$ 2807-2813. (doi:10.2337/db12-0239)

Kaminska D, Kakela P, Nikkola E, Venesmaa S, Ilves I, Herzig KH, Kolehmainen M, Karhunen L, Kuusisto J, Gylling H, et al. 2016 Regulation of alternative splicing in human obesity loci. Obesity $\mathbf{2 4}$ 2033-2037. (doi:10.1002/oby.21587)

Kandpal RP, Rajasimha HK, Brooks MJ, Nellissery J, Wan J, Qian J, Kern TS \& Swaroop A 2012 Transcriptome analysis using next generation sequencing reveals molecular signatures of diabetic retinopathy and efficacy of candidate drugs. Molecular Vision 18 1123-1146.

Kawaki J, Nagashima K, Tanaka J, Miki T, Miyazaki M, Gonoi T, Mitsuhashi N, Nakajima N, Iwanaga T, Yano H, et al. 1999 Unresponsiveness to glibenclamide during chronic treatment induced by reduction of ATP-sensitive K+ channel activity. Diabetes 48 2001-2006. (doi:10.2337/diabetes.48.10.2001)

Kibiti CM \& Afolayan AJ 2015 Herbal therapy: a review of emerging pharmacological tools in the management of diabetes mellitus in Africa. Pharmacognosy Magazine 11 S258-S274. (doi:10.4103/09731296.166046)

Kokil GR, Veedu RN, Ramm GA, Prins JB \& Parekh HS 2015 Type 2 diabetes mellitus: limitations of conventional therapies and intervention with nucleic acid-based therapeutics. Chemical Reviews 115 4719-4743. (doi:10.1021/cr5002832)
Kozyrev SV, Abelson AK, Wojcik J, Zaghlool A, Linga Reddy MV, Sanchez E, Gunnarsson I, Svenungsson E, Sturfelt G, Jonsen A, et al. 2008 Functional variants in the B-cell gene BANK1 are associated with systemic lupus erythematosus. Nature Genetics 40 211-216. (doi:10.1038/ng.79)

Kutlu B, Burdick D, Baxter D, Rasschaert J, Flamez D, Eizirik DL, Welsh N, Goodman N \& Hood L 2009 Detailed transcriptome atlas of the pancreatic beta cell. BMC Medical Genomics 2 3. (doi:10.1186/17558794-2-3)

Ladomery MR, Harper SJ \& Bates DO 2007 Alternative splicing in angiogenesis: the vascular endothelial growth factor paradigm. Cancer Letters 249 133-142. (doi:10.1016/j.canlet.2006.08.015)

Lee Y \& Rio DC 2015 Mechanisms and regulation of alternative premRNA splicing. Annual Review of Biochemistry 84 291-323. (doi:10.1146/annurev-biochem-060614-034316)

Li JH, Huang XR, Zhu HJ, Oldfield M, Cooper M, Truong LD, Johnson RJ \& Lan HY 2004 Advanced glycation end products activate Smad signaling via TGF-beta-dependent and independent mechanisms: implications for diabetic renal and vascular disease. FASEB Journal 18 176-178. (doi:10.1096/fj.04-2273com)

Liu H, Yu S, Zhang H \& Xu J 2012 Angiogenesis impairment in diabetes: role of methylglyoxal-induced receptor for advanced glycation endproducts, autophagy and vascular endothelial growth factor receptor 2. PLOS ONE 7 e46720. (doi:10.1371/journal.pone.0046720)

Lorini R, Klersy C, d'Annunzio G, Massa O, Minuto N, Iafusco D, Bellanne-Chantelot C, Frongia AP, Toni S, Meschi F, et al. 2009 Maturity-onset diabetes of the young in children with incidental hyperglycemia: a multicenter Italian study of 172 families. Diabetes Care 32 1864-1866. (doi:10.2337/dc08-2018)

Malakar P, Chartarifsky L, Hija A, Leibowitz G, Glaser B, Dor Y \& Karni R 2016 Insulin receptor alternative splicing is regulated by insulin signaling and modulates beta cell survival. Scientific Reports 631222 (doi:10.1038/srep31222)

Malviya N, Jain S \& Malviya S 2010 Antidiabetic potential of medicinal plants. Acta Poloniae Pharmaceutica 67 113-118.

Mao XQ, Wu Y, Wu K, Liu M, Zhang JF, Zou F \& Ou-Yang JP 2007 Astragalus polysaccharide reduces hepatic endoplasmic reticulum stress and restores glucose homeostasis in a diabetic KKAy mouse model. Acta Pharmacologica Sinica 28 1947-1956. (doi:10.1111/j.1745-7254.2007.00674.x)

McKenzie MD, Carrington EM, Kaufmann T, Strasser A, Huang DCS, Kay TWH, Allison J \& Thomas HE 2008 Proapoptotic BH3-only protein bid is essential for death receptor-induced apoptosis of pancreatic $\beta$-cells. Diabetes 57 1284-1292. (doi:10.2337/db07-1692)

Mironidou-Tzouveleki M, Tsartsalis S \& Tomos C 2011 Vascular endothelial growth factor (VEGF) in the pathogenesis of diabetic nephropathy of type 1 diabetes mellitus. Current Drug Targets 12 107-114. (doi:10.2174/138945011793591581)

Montes M, Cloutier A, Sanchez-Hernandez N, Michelle L, Lemieux B, Blanchette M, Hernandez-Munain C, Chabot B \& Sune C 2012 TCERG1 regulates alternative splicing of the Bcl-x gene by modulating the rate of RNA polymerase II transcription. Molecular and Cellular Biology 32 751-762. (doi:10.1128/MCB.06255-11)

Moore MJ, Wang Q, Kennedy CJ \& Silver PA 2010 An alternative splicing network links cell-cycle control to apoptosis. Cell $\mathbf{1 4 2}$ 625-636. (doi:10.1016/j.cell.2010.07.019)

Mourich DV, Oda SK, Schnell FJ, Crumley SL, Hauck LL, Moentenich CA, Marshall NB, Hinrichs DJ \& Iversen PL 2014 Alternative splice forms of CTLA- 4 induced by antisense mediated spliceswitching influences autoimmune diabetes susceptibility in NOD mice. Nucleic Acid Therapeutics 24 114-126. (doi:10.1089/ nat.2013.0449)

Nattrass M \& Lauritzen T 2000 Review of prandial glucose regulation with repaglinide: a solution to the problem of hypoglycaemia in the treatment http://jme.endocrinology-journals.org

DOI: 10.1530/JME-17-0049
๑) 2017 Society for Endocrinology Printed in Great Britain
Published by Bioscientifica Ltd 
of Type 2 diabetes? International Journal of Obesity and Related Metabolic Disorders 24 (Supplement 3) S21-S31. (doi:10.1038/sj.ijo.0801422)

Noble JA \& Valdes AM 2011 Genetics of the HLA region in the prediction of type 1 diabetes. Current Diabetes Reports 11 533-542. (doi:10.1007/s11892-011-0223-x)

Nogueira TC, Paula FM, Villate O, Colli ML, Moura RF, Cunha DA, Marselli L, Marchetti P, Cnop M, Julier C, et al. 2013 GLIS3, a susceptibility gene for type 1 and type 2 diabetes, modulates pancreatic beta cell apoptosis via regulation of a splice variant of the BH3-only protein Bim. PLoS Genetics 9 e1003532. (doi:10.1371/ journal.pgen.1003532)

Olokoba AB, Obateru OA \& Olokoba LB 2012 Type 2 diabetes mellitus: a review of current trends. Oman Medical Journal 27 269-273. (doi:10.5001/omj.2012.68)

Oltean S, Gammons M, Hulse R, Hamdollah-Zadeh M, Mavrou A, Donaldson L, Salmon AH, Harper SJ, Ladomery MR \& Bates DO 2012 SRPK1 inhibition in vivo: modulation of VEGF splicing and potential treatment for multiple diseases. Biochemical Society Transactions 40 831-835. (doi:10.1042/BST20120051)

Ozcan U, Cao Q, Yilmaz E, Lee AH, Iwakoshi NN, Ozdelen E, Tuncman G, Gorgun C, Glimcher LH \& Hotamisligil GS 2004 Endoplasmic reticulum stress links obesity, insulin action, and type 2 diabetes. Science 306 457-461. (doi:10.1126/science.1103160)

Pihlajamaki J, Lerin C, Itkonen P, Boes T, Floss T, Schroeder J, Dearie F, Crunkhorn S, Burak F, Jimenez-Chillaron JC, et al. 2011 Expression of the splicing factor gene SFRS10 is reduced in human obesity and contributes to enhanced lipogenesis. Cell Metabolism 14 208-218. (doi:10.1016/j.cmet.2011.06.007)

Sakamoto Y, Inoue H, Keshavarz P, Miyawaki K, Yamaguchi Y, Moritani M, Kunika K, Nakamura N, Yoshikawa T, Yasui N, et al. 2007 SNPs in the KCNJ11-ABCC8 gene locus are associated with type 2 diabetes and blood pressure levels in the Japanese population. Journal of Human Genetics 52 781-793. (doi:10.1007/s10038-007-0190-x)

Santin I \& Eizirik DL 2013 Candidate genes for type 1 diabetes modulate pancreatic islet inflammation and beta-cell apoptosis. Diabetes, Obesity and Metabolism 15 (Supplement 3) 71-81. (doi:10.1111/dom.12162)

Schmid D, Stolzlechner M, Sorgner A, Bentele C, Assinger A, Chiba P \& Moeslinger T 2012 An abundant, truncated human sulfonylurea receptor 1 splice variant has prodiabetic properties and impairs sulfonylurea action. Cellular and Molecular Life Sciences 69 129-148. (doi:10.1007/s00018-011-0739-x)

Semenya S, Potgieter M \& Erasmus L 2012 Ethnobotanical survey of medicinal plants used by Bapedi healers to treat diabetes mellitus in the Limpopo Province, South Africa. Journal of Ethnopharmacology 141 440-445. (doi:10.1016/j.jep.2012.03.008)

Seol DW \& Billiar TR 1999 A caspase-9 variant missing the catalytic site is an endogenous inhibitor of apoptosis. Journal of Biological Chemistry 274 2072-2076. (doi:10.1074/jbc.274.4.2072)

Spitali P \& Aartsma-Rus A 2012 Splice modulating therapies for human disease. Cell 148 1085-1088. (doi:10.1016/j.cell.2012.02.014)

Storling J \& Pociot F 2017 Type 1 diabetes candidate genes linked to pancreatic islet cell inflammation and beta-cell apoptosis. Genes $\mathbf{8}$ article 72. (doi:10.3390/genes8020072)

Sujjitjoon J, Kooptiwut S, Chongjaroen N, Tangjittipokin W, Plengvidhya N \& Yenchitsomanus PT 2016 Aberrant mRNA splicing of paired box 4 (PAX4) IVS7-1G\&gt;A mutation causing maturityonset diabetes of the young, type 9. Acta Diabetologica 53 205-216. (doi:10.1007/s00592-015-0760-x)

Sun X, Sui W, Wang X, Hou X, Ou M, Dai Y \& Xiang Y 2016 Wholegenome re-sequencing for the identification of high contribution susceptibility gene variants in patients with type 2 diabetes. Molecular Medicine Reports 13 3735-3746. (doi:10.3892/ mmr.2016.5014).

Thomas HE, McKenzie MD, Angstetra E, Campbell PD \& Kay TW 2009 Beta cell apoptosis in diabetes. Apoptosis 14 1389-1404. (doi:10.1007/s10495-009-0339-5)

Tomita T 2016 Apoptosis in pancreatic beta-islet cells in Type 2 diabetes. Bosnian Journal of Basic Medical Sciences 16 162-179.

Tomita T 2017 Apoptosis of pancreatic beta-cells in Type 1 diabetes. Bosnian Journal of Basic Medical Sciences 17 [in press]. (doi:10.17305/ bjbms.2016.919)

van Huyssteen M, Milne PJ, Campbell EE \& van de Venter M 2011 Antidiabetic and cytotoxicity screening of five medicinal plants used by traditional African health practitioners in the Nelson Mandela Metropole, South Africa. African Journal of Traditional, Complementary and Alternative Medicines 8 150-158. (doi:10.17305/ bjbms.2017.1961)

Vandiedonck C, Taylor MS, Lockstone HE, Plant K, Taylor JM, Durrant C, Broxholme J, Fairfax BP \& Knight JC 2011 Pervasive haplotypic variation in the spliceo-transcriptome of the human major histocompatibility complex. Genome Research 21 1042-1054. (doi:10.1101/gr.116681.110)

Villate O, Turatsinze JV, Mascali LG, Grieco FA, Nogueira TC, Cunha DA, Nardelli TR, Sammeth M, Salunkhe VA, Esguerra JL, et al. 2014 Nova1 is a master regulator of alternative splicing in pancreatic beta cells. Nucleic Acids Research 42 11818-11830. (doi:10.1093/nar/ gku861)

Wang L, Miura M, Bergeron L, Zhu H \& Yuan J 1994 Ich-1, an Ice/ced-3related gene, encodes both positive and negative regulators of programmed cell death. Cell 78 739-750. (doi:10.1016/S00928674(94)90422-7)

Ward AJ \& Cooper TA 2010 The pathobiology of splicing. Journal of Pathology 220 152-163. (doi:10.1002/path.2649)

World Health Organization 2016 Global Report on Diabetes. Geneva, Switzerland: WHO

Yamauchi T, Hara K, Maeda S, Yasuda K, Takahashi A, Horikoshi M, Nakamura M, Fujita H, Grarup N, Cauchi S, et al. 2010 A genomewide association study in the Japanese population identifies susceptibility loci for type 2 diabetes at UBE2E2 and C2CD4AC2CD4B. Nature Genetics 42 864-868. (doi:10.1038/ng.660)

Yip L, Fuhlbrigge R, Taylor C, Creusot RJ, Nishikawa-Matsumura T, Whiting CC, Schartner JM, Akter R, von Herrath M \& Fathman CG 2015 Inflammation and hyperglycemia mediate Deaf1 splicing in the pancreatic lymph nodes via distinct pathways during type 1 diabetes. Diabetes 64 604-617. (doi:10.2337/db14-0803)

Zeggini E, Scott LJ, Saxena R, Voight BF, Marchini JL, Hu T, de Bakker PI, Abecasis GR, Almgren P, Andersen G, et al. 2008 Meta-analysis of genome-wide association data and large-scale replication identifies additional susceptibility loci for type 2 diabetes. Nature Genetics $\mathbf{4 0}$ 638-645. (doi:10.1038/ng.120)

Received in final form 9 May 2017

Accepted 30 May 2017

Accepted Preprint published online 31 May 2017 http://jme.endocrinology-journals.org

DOI: 10.1530/JME-17-0049
() 2017 Society for Endocrinology Printed in Great Britain
Published by Bioscientifica Ltd 